\title{
Settlement of Problematic Loans in the Unit Pengelola Kegiatan (UPK) of Pidie District did Sharia
}

\author{
Nufiar, Mariana, Muhammad Ali \\ Al-Hilal College of Sharia Science Sigli, Pidie-Aceh 24151, Indonesia \\ Resort Police Pidie, Pidie-Aceh 24151, Indonesia
}

Email:marianamer02@gmail.com

\section{ARTICLE INFO}

Date received : 01 August 2020

Revision date : 25 August 2020

Date received : 12 September 2020

Keywords:

Loans

Problematic Loans

Unit Pengelola Kegiata

Sharia

\begin{abstract}
This research aims to determine the cause of problematic credit in UPK Pidie district and problematic credit settlement procedures in UPK Pidie District as well as the settlement of problematic credit on UPK in Pidie district according to Sharia. Results of the study showed that the main factor of the cause of problematic credit in the UPK of Pidie District is because of business and business results that do not match the expectations plus more household needs that are increasingly increasing the day, earnings that do not meet the needs. Also and credit given is not fully used for capital, there are groups using loans for household needs. The problematic credit settlement procedure for UPK Pidie District is by conducting a field review, conducting coaching many times by continuing to spur the group to pay by the next set time with restructuring efforts. The settlement of problematic credit in the UPK Pidie District is appropriate because the UPK does not attract the angling but always takes a family path with the affected group members.
\end{abstract}

\section{INTRODUCTION}

Entering the era of globalization with the rapid development of the economy, not few companies emerge with various fields of business. Such conditions cause the company to experience increasingly competitive competition in the effort to break through the market share of the domestic and international markets to achieve the sales target set by the management.

Small business is one of the efforts to alleviate poverty, hence the Government provides capital means to develop its business. Governmentprogrammed economic development is emphasized on the equalization element, one of which is equitable in the opportunity to strive. The Government in this case provides a broader opportunity to the community, especially the less capable community in strengthening the capital so that thereby equitable the opportunity to strive for the expected will be realized. The people's economy here is the center of the community's economic development which is developing relatively slowly, with conditions inherent in certain groups of society.

People's economy is economic development of a community that develops relatively slowly, by the conditions inherent in certain communities (Rasyidah et al., 2018). The Program of lending to the community is based on worthiness, as it is known that it is supposed that people's lives should be lifted from the indigent and poverty (Turmuzi, 2012). Therefore, the government is trying to stretch out its hand and extend its reach so that the 
economic movements of society become more rapid.

The government program is the National Program for Community Empowerment in Rural Areas, hereinafter abbreviated as PNPM-MP in 2007, to overcome poverty, PNPM Mandiri is a national program for poverty reduction based on community empowerment. The forms of activities in the implementation of PNPM-MP in Pidie District are programs to improve the quality of life through a variety of assistance and training, construction of physical facilities and infrastructure, as well as credit assistance through the Productive Economy Unit and Women's Loans and Loans which channel funds given to community groups in Village and managed by the Unit Pengelola Kegiatan (www.pnpm-mandiri.org).

The decision-making process for granting credit is very important. The Unit Pengelola Kegiatan will conduct an analysis of each credit submitted carefully using all available information before deciding or rejecting each credit application. If the debtor agrees, the prospective debtor will receive an offer letter or conditional approval letter from the bank (Mariana et al., 2018). Crediting decisions are important for financial institutions because they relate to the loss and sustainability of the institution. However, asking for credit carries risks, so it must be done with caution which ultimately creates difficulties (Mariana et al., 2018).

Problematic loans can be interpreted as credits that have difficulty in repayment due to an accidental factor and or due to external factors beyond the ability of the debtor's control. The problematic credits are also often called nonperforming loan (NPL), can be measured from the collection(Fransisca Claudya Mewoh et al., 2016). There are problems in credit and solutions must be sought both by family and court. The settlement is carried out by the UPK of Pidie Regency, namely by the road and Sharia rules that apply. With the possibility of resolving disputes taken by way of deliberation, mediation in groups and community leaders, arbitration institutions, or through courts in the General Courts as long as agreed in the Contract by the parties.

Based on the explanation above, the problem formulation in this credit is what causes the occurrence of problem loans and how is the credit settlement procedure at Pidie Regency Unit Pengelola Kegiatan?

\section{THEORY Credit}

Credit is the provision of money or the bills that can be likened to it based on the approval of the loan-borrowing between the bank and other parties in the event, the borrower is obliged to refund the amount of money borrowed and the interest by the agreement. While the other opinion stated that bank credit is all realization of credit in the form of rupiah and foreign exchange to third parties and the purchase of securities. While in Indonesian terminology, credit is defined as a money loan with a payment of refund (Abdullah, 2019).

Credit is to trust the recipient of the credit, that the credit that is channeled will be refunded under the agreement. Credit decision making is a kind of feasibility study for credit applicant companies. Credit decision making is an examination, research, and analysis of the completeness, validity, and feasibility of the file/letter/data of the prospective debtor credit to the issuance of a decision whether the credit was received or rejected (Mariana, 2016).

\section{Unit Pengelola Kegiatan (UPK)}

The Unit Pengelola Kegiatan (UPK) is an institution established by the community in the Forum of the proposed MAD priorities and serves to help manage activities including channeling public aid funds in PNPM. In carrying out the activities of UPK is responsible for the deliberation Forum between villages as representatives of communities in the subdistrict, UPK is no longer only as a cashier (the clerk) but more than that is also responsible for the success of all PNPM activities in the district (www.pnpm-mandiri.org).

\section{METODE}

The research method that authors use in this study is a descriptive analysis of a method by which the problem solving is investigated by describing or depicting the state of the subject or the object of research at the present moment based on the facts that seem or as it is. The Research approach used in this research is qualitative. Qualitative method is a research procedure that generates descriptive data of written or spoken words from people and behaviors observed (Mariana \& Murthaza, 2019).

The type of research used is the recharch field, which is a method of collecting data in qualitative research that does not require indepth knowledge of the literature used and the special abilities of researchers (Mariana \& Murthaza, 2019).

\section{RESULTS AND DISCUSSION \\ Factors Causing the Problem of Problematic Credit on UPK Pidie District}

Credit is the provision of money or charges that can be likened to, based on the agreement or agreement between the bank and the other party that requires the financed party to return the money or the charge after a certain period in return or for 
the outcome, every credit is never detached from the issue. Before explaining more about the factors that are the reason for problematic credit in the UPK of Pidie District, first look at the credit system in practice.

According to Maulizar in lending, a group member must submit a proposal that the UPK then examines the proposal which is subsequently handed over to the verification team, and by the verifications team who will check the space immediately to see whether or not the group is funded, if feasible it will be handed over to the funding party to look back how much the funds deserve to the group. And currently, UPK Pidie District has been practicing the credit of sharia patterns. For now, there is a 118 SPP group of Pidie District which is still active.

A problematic credit or Non-Performing Loan (NPL) is an overview of the situation, where the loan repayment agreement is at risk of failure, even likely to be a potential loss. The presence of problematic credit in high numbers will cause difficulties at once will decrease the health level of the bank concerned. Increased problematic loans resulted in UPK having to provide a considerable reserve of receivables removal, i.e. $1 \%$ for current credit type, $25 \%$ for credit in case attention, $50 \%$ for less current credits, $75 \%$ for doubtful credits and $100 \%$ for bad credit, so that the credit channeling ability becomes very limited.

For the time being in UPK district Pidie, 15 SPP groups are experiencing jammed or entered problematic group categories. In the UPK of Pidie district if late payment is 2 times the group is already in trouble. The same is also conveyed by Nelliyana as the chairman of UPK Pidie District, 15 groups are currently in the category of jams and there are already 4 times do not make payments. This is because the group effort is not smooth, and credit given is not fully used for the capital, there is a group that uses loans for household needs so that it results in the payment of loans that are not smooth, so the member's income is also not by the planned return target every month.

Furthermore, the Group Chairman of Manggis added that their SPP group has been delinquent for a year because of business and business results that do not match the expectations plus more household needs that are increasingly increasing the day, earnings that do not meet the needs. And group members are also very trying to pay off but what many powers among the group members are also very very current economic flops.

Factors causing problematic credit caused by members of SPP group are problematic also because of unfixed customer income, SPP Group members do not notify income or net income of doing so, installments elsewhere are not discussed to the party UPK, loan credit is not equal to the balance of customer income every month. Also, the lack of human resources in marketing so that customers who have done credit in UPK Pidie District can not be controlled optimally, too easy to apply credit requirements, less thorough in conducting surveys before giving credit.

Based on the explanation above can be concluded that the main factor in the cause of problematic credit in the UPK Pidie District is because of the business and the results of a business that does not match the expectations plus more household needs that are increasingly increasing the day, earnings that do not meet the needs. Also and credit given is not fully used for capital, there is a group that uses loans for household needs, lack of human resources in marketing so that customers who have done credit in UPK Pidie District can not be controlled optimally, too easy to apply credit requirements, less thorough in conducting surveys before giving credit.

\section{Procedure to settle credit settlement on UPK Pidie District}

The problematic credit is a credit that is not smooth, credit where the borrower does not meet the promised requirements, credit that does not keep the installment schedule, credit that has the potential of adverse UPK. To minimize UPKproblematic credits along with the ranks directly conduct field review, do the coaching many times by continuing to spur the group to keep paying by the stipulated time.

UPK Pidie's party in completing the credit that the problem is prioritizing the use of negotiations and deliberations first because UPK argues that settlement through negotiation and deliberation is the best way and safely settle the problem credits. When the problem credits arise, the initial handling by UPK of Pidie District is reminiscent of customers, in this case hoping that the customer's awareness to pay the installment.

Furthermore, Maulizar also added efforts made by UPK District Pidie if the group has been problematic is to relieve SPP group members in payment by rescheduling the payment so that group members can deposit payment with several installments smaller than before with the added period.

All members of the group are treated equally indiscriminately, in the case of arrears, because if the problematic credits continue longer. This will result in declining UPK revenues, and the most fatal thing is being followed by other groups to opt-out of paying on time. If this happens then the UPK will undergo bankruptcy slowly. Subsequently, Maulizar added that the parties involved in the problem resolution were the UPK, the verification team, and the founding team.

The current pattern of credit settlement UPK do is a pattern that is already used by even the average credit, but UPK Pidie District still strives to 
comply with the rules of Sharia, and UPK Pidie District to this day continue to try and strive and desperately need guidance from any party regarding the settlement of problematic credit in the ShariaTreasures. This is justified by Nelliyana, which is where the initial step in resolving the problem is to make a peaceful walk.

Based on the explanation above, it can be concluded that the problematic credit settlement procedure in the UPK of Pidie District is by conducting a field review, conducting coaching many times by continuing to spur the group to keep paying by the stipulated time. And with a Restructuring effort if the SPP group still has a good faith, but if the SPP group is not in good faith in the sense can not be invited to cooperate in the rescue of problematic credit then UPK Pidie District will make efforts to settle the problem credit.

\section{Settlement of problematic loans in the UPK of Pidie according to Syari'ah}

Islam strongly encourages to settle the debt if it can pay it regardless of responsibility because it belongs to the haqqul ' Adami. If someone can pay debts but he does not do so he is categorized as having acted wrongdoing. But another case, if the person who owes the debt in a predicament or has not been able to repay his debts. To the issue, Islam strongly encourages the UPK to provide delayed payment of the grace period given or even abolished the debt if the SPP group is in a very difficult/urgent state, or perhaps the creditor may forgive and release the debtor (al-lbra') and consider the debt as charity or zakat obligatory because the person who is owed is entitled to receive zakat. As the word of God in QS. AlBaqarah 280 which means and if (the one who owes it) in tribulation, then give tough until he is twinning. It is better for you, if you know that, for you.

In line with the development of sharia financial institutions so that spur products and services to serve the needs of the community. One of the SPP credits offered by UPK in Pidie District also follows the pattern of sharia. Efforts made by UPK Pidie District to handle the problematic credit by doing a rescue of problematic credit with a Restructuring effort if the SPP group still has good faith in the sense still want to be invited to cooperate in the effort to rescue the problem credit, but if the SPP group is not in good faith in the sense can not be invited cooperation in the effort to rescue the problematic credit then the

The credit that is practiced in the UPK of Pidie district is by Islamic rules, although there is still a need to be addressed. And in solving the problem in UPK he has also been involved, especially the problem of contract in the process of credit. The problem solving the credit that is practiced in UPK has been almost by the Sharia, but it is a little more in the reporting section. And according to Sharia problem solving is appropriate because the UPK does not attract collateral but always takes a family path with the group of problematic members.

Based on the explanation above, it can be concluded that the problem of credit settlement on UPK Pidie District is appropriate because UPK does not attract collateral but always take a family path with problematic group members.

\section{CONCLUSION}

The main factor in the cause of problematic credit in the UPK of Pidie District is because of business and business results that do not match the expectations plus more household needs that are increasingly increasing, income that does not meet the needs. Also and credit given is not fully used for capital, there is a group that uses loans for household needs, lack of human resources in marketing so that customers who have done credit in UPK Pidie District can not be controlled optimally, too easy to apply credit requirements, less thorough in conducting surveys before giving credit.

The problematic credit settlement procedure for UPK Pidie District is by conducting a field review, conducting coaching many times by continuing to spur the group to keep paying by the stipulated time. And with a Restructuring effort if the SPP group still has a good faith, but if the SPP group is not in good faith in the sense can not be invited to cooperate in the rescue of problematic credit then UPK Pidie District will make efforts to settle the problem credit.

The settlement of problematic credit on UPK Pidie District is appropriate because the UPK does not attract collateral but always takes a family path with the group of problematic members.

\section{REFERENCES}

Abdullah, A. (2019). Pinjaman Kredit Dalam Perspektif Pendidikan Islam. Jurnal Hukum Ekonomi Syariah, 3(1), 40- 52. https://doi.org/10.26618/j-hes.v3i1.2122

Fransisca Claudya Mewoh, Sumampouw, H. J., \& Tamengkel, L. F. (2016). Jurnal Administrasi Bisnis. Cell, 4(1), 1- 15. https://doi.org/10.1016/j.cell.2009.01.043

Mariana. (2016). Pengaruh Return on Investment, Current Ratio, Debt to Equity Ratio Terhadap Pengambilan Keputusan Kredit pada PT. Bank Rakyat Indonesia (Persero), Tbk Cabang Sigli Unit Meureudu dan PT. Bank Syariah Mandiri Office Meureudu. Jurnal Akuntansi Dan Keuangan, 5(1), 85-90. https://www.researchgate.net/publication/342 378375 
Mariana, \& Murthaza, M. (2019). Etika Bisnis dalam Perspektif Hukum Islam (Studi Kasus pada Swalayan Kota Sigli). Tahqiqa, 13(1), 62-72. https://www.researchgate.net/publication/342 378823

Mariana, Nadiarsyah, \& Abdullah, S. (2018). Informasi Akuntansi, Informasi NonAkuntansi, dan Keputusan Pemberian Kredit. Jurnal Reviu Akuntansi Dan Keuangan, 8(2), 177-186. https://doi.org/10.22219/jrak.v8i

Rasyidah, Husna, N., \& Safrianti, L. (2018). Pemberdayaan Ekonomi Keluarga Melalui
Budidaya Kota Banda Aceh. Jurnal Alljtimaiyyah, 4(1), 70-87.

Turmuzi. (2012). Pelaksanaan Perjanjian Kredit Tanpa Jaminan Antara Kelompok Simpan Pinjam Dengan Unit Pengelola Kegiatan Program Nasional Pemberdayaan Masyarakat (PNPM) Mandiri di Desa Sungai Cina Kecamatan Rangsang Barat. Skripsi, Riau, Universitas Islam Negerisultan Syarif Kasim.

\section{Copyright holder:}

Nufiar, Mariana, Muhammad Ali (2020)

First publication right :

Journal of Social Science

This article is licensed under:

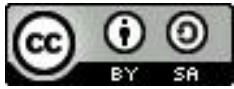

